\title{
An investigation on the effects of conservatism on reducing risk of stock market investment: A case study of Tehran Stock Exchange
}

\author{
Rezvan Hejazi $^{\mathrm{a}}$ and Sahar Rostamnejad ${ }^{\mathrm{b}^{*}}$
}

${ }^{a}$ Professor \& Faculty Member, Department of Accounting, Al-Zahra University, Tehran, Iran

${ }^{b}$ M.Sc. Student, Department of Accounting, School of Management, Tehran North Branch, Islamic Azad University (IAU), Tehran, Iran

\section{H R O N I C L E}

\section{Article history:}

Received May 12, 2013

Received in revised format

25 June 2013

Accepted 27 June 2013

Available online

June 282013

Keywords:

Tehran Stock Exchange

Negative return skewness

Stock price crashes \begin{abstract}
A B S T R A C T
Accounting conservatism limits managerial incentive and ability to overstate performance and hide bad news from investors, which, in turn, reduces stock price crash risk. This study examines relationship between conservatism on financial reports and risk of stock price crash. Using a sample of 54 listed firms in Tehran Stock Exchange over the period of 2006-2010 and panel logistic regression, we examine different hypotheses. The results indicate that accounting conservatism, as measured by Khan and Watts (2009) CSCORE [Khan, M., \& Watts, R. L. (2009). Estimation and empirical properties of a firm-year measure of accounting conservatism. Journal of Accounting and Economics, 48(2), 132-150.], reduces the likelihood of a firm experiencing stock price crashes. The finding holds after controlling other variables such as: negative skewness of firm-specific-weekly return, standard deviation of firm-specific-weekly return, the mean of firm-specific-weekly return, detrend share turnover, size, market to book value of equity ratio, total debt ratio and return on asset ratio, but we did not observe any relationship between these variables during stock price crash.
\end{abstract}

\section{Introduction}

Accounting conservatism plays an essential role on discounting investor irrational exuberance and there are many studies to investigate the effect of this kind of accounting system on stock market (Hutton et al., 2009; Kothari et al., 2009; Van Buskirk, 2009; Ball et al., 2010). Ahmed and Duellman (2007) considered three different measures of conservatism and investigated whether or not the percentage of inside directors was negatively associated with conservatism, and whether the percentage of outside directors' shareholdings was positively associated with conservatism. They reported that after controlling for industry, firm size, leverage, growth opportunities, institutional 
ownership, inside director ownership, and unobservable firm characteristics that were stable over time. According to their survey, there were some consistent evidences to believe that accounting conservatism could assist directors in reducing agency costs of firms (Ball et al., 2009). Beekes et al. (2004) performed similar investigation by studying the link between earnings timeliness, earnings conservatism and board composition: evidence from the UK and found somewhat similar results. Bekaert and Wu (2000) investigated asymmetric volatility and risk in equity markets. Chen et al. (2001) investigated forecasting crashes by looking on trading volume, past returns, and conditional skewness in stock prices. LaFond and Watts (2008) performed an empirical investigation on the information role of conservatism.

Normally, when interest rates are at low levels, many firms try to expand their operations through borrowing money from banks or other financial institutions. However, there must be some conservatism on the amount and timing of borrowing money (Ball et al., 2008). When the ratio of debt to equity goes up, the risk on bankruptcy will increase and investors may look for alternative methods for protecting their investment such as purchasing put options (Bates, 2000). Boyer et al. (2010) examined the prediction of recent theories that stocks with high idiosyncratic skewness could have low expected returns. They reported that that expected skewness could help explain the phenomenon that stocks with high idiosyncratic volatility have low expected returns. Braun et al. (1995) investigated the effects of good, bad and so called ugly news on beta as a measure of stock market volatility. Bushman and Piotroski (2006) studied the effects of financial reporting incentives for conservative accounting by looking into the effect of legal and political institutions. On stock market, normally, there is a famous word: no news is good news. Campbell and Hentschel (1992) investigated this issue by presenting an asymmetric model of changing volatility in stock returns and confirmed the claim.

Chung and Wynn (2008) investigated the impact of managerial legal liability coverage on earnings conservatism. They reported that the higher the managerial liability coverage, which reduces the expected legal liability of managers, the less conservative the firm's earnings based on directors' and officers' (D\&O) liability insurance coverage and cash for indemnification as a proxy for managerial legal liability coverage. They also reported that managerial legal liability coverage had a stronger impact on earnings conservatism in a legal regime with higher litigation risk. The results were consistent with the threat of litigation conditioning managers to practice conservative accounting. Dhaliwal et al. (2008) investigated product market competition and accounting conservatism. Dierker (2006) provided a theory of mandatory accounting conservatism as a tool to prevent speculative bubbles and overvaluation. In a simple exchange economy where agents trade due to differences in opinion, they demonstrated that conservatism could lead to a lower expected stock price than a full disclosure regime. Therefore, conservatism matters as investors cannot undo the known bias in the system. However, they explained how conservatism hurts market efficiency in a frictionless, perfectly efficient financial market. They also explained how mandatory conservative standards such as the SEC's former could ban on upward revisions of asset valuations can indeed curb in potential bubbles. Dimson (1979) considered risk measurement when shares are subject to infrequent trading. Marin and Olivier (2008) performed a comprehensive study on what could happen when stock market crashes. Roychowdhury and Watts (2007) studied asymmetric timeliness of earnings, market-to-book and conservatism in financial reporting.

According to Duffee (1995) individual firms' stock return volatility rises after stock prices fall. Duffee (1995) reported that this statistical relationship was largely due to a positive contemporaneous relation between firm stock returns and firm stock return volatility and at the aggregate level, the sign of this contemporaneous relationship was reversed. Glosten et al. (1993) investigated the relationship between the expected value and the volatility of the nominal excess return on stocks. The reasons for the difference between the aggregate- and firm-level relations are explored. Frankel and Roychowdhury (2007) forecasted the persistence of large negative special items based on expected 
accounting conservatism. They reported that negative special items of some firms were less closely tied to contemporaneous returns and were more persistent with respect to future net income. In addition, they reported that the variation in special-items persistence did not simply reflect variation in the persistence of all earnings components, nor was it restricted to firms that just met earnings targets. Lara et al. (2009) forecasted that firms with stronger corporate governance would exhibit a higher degree of accounting conservatism. Hong and Stein (2003) considered differences of opinion, short-sales constraints, and market crashes. Khan and Watts (2009) investigated the issue of estimation and empirical properties of a firm-year measure of accounting conservatism. Norton et al. (2004) explained why computing the marginal impact of a change in two variables is more complicated in nonlinear models than in linear models. Qian (2007) investigated the impacts of contracting, litigation, regulation, and tax costs on conditional and unconditional conservatism using a cross-sectional evidence at the firm level. Zhang (2008) investigated the contracting advantages of accounting conservatism to lenders and borrowers.

\section{The proposed study}

The proposed study of this paper considers the financial information of the firms listed on Tehran Stock Exchange based some criteria over the period of 2006-2010. In our survey, only firms selected whose shares were active during the period of study, they marinated, at least 100 active trading days and they must have the same fiscal year ending March. In addition, we set aside the information of financial and holding firms such as banks and only considered firms with positive equities. The main hypothesis of this survey is as follows,

Main hypothesis: Conservatism reduces the chance of stock market crash.

The proposed study uses regression technique where conservatism is the independent variable and the likelihood of crash is the dependent variables. In addition, we have used eight control variables including the re-circulating shares (DTURN), negative skewness of weekly returns (NCSKEW), standard deviation of weekly return, firm size, the ratio of long term debts to total assets, market value to book value and the ratio of profit before extraordinary items to total assets $\left(X_{j t}\right)$. The proposed study uses a model introduced by Khan and Watts (2009) as follows,

$X_{j t}=\beta_{1 t}+\beta_{2 t} D_{j t}+\beta_{3 j t} R_{j t}+\beta_{4 j t} D_{j t} * R_{j t}+\varepsilon_{j t}$,

where $R_{j t}$ is the yearly return of firm $j$ at time $t, D_{j t}$ is a dummy variable which is one when the firm $j$ at time $t$ reported negative return and zero, otherwise. In addition, $\beta_{1 t}, \beta_{2 t}, \beta_{3 j t}$ and $\beta_{4 j t}$ are estimated coefficients and $\varepsilon_{j t}$ represents error term, respectively. In Eq. (1), $\beta_{3 \mathrm{j}, \mathrm{t}}$ is the time for predicting good events and it is estimated through the following equation,

GSCORE $\equiv \beta_{3 j t}=\mu_{1 t}+\mu_{2 t} M K V_{j t}+\mu_{3 t} M B_{j t}+\mu_{4 t} L E V_{j t}$,

where $M K V_{j t}$ is the natural logarithm of market value, $M B_{j t}$ is market value to book value $L E V_{j t}$ is the ratio of the ratio of long term debts to total assets for firm $j$ at time $t$. In addition, $\mu_{1 t}$ represents the intercept and $\mu_{2 t}, \mu_{3 t}$ and $\mu_{4 t}$ are coefficients to be estimated. Similarly, we may find the event of bad news through the following equations,

$\operatorname{CSCORE} \equiv \beta_{4 j t}=\lambda_{1 t}+\lambda_{2 t} M K V_{j t}+\lambda_{3 t} M B_{j t}+\lambda_{4 t} L E V_{j t}$

Using Eq. (2) and Eq. (3), Eq. (1) becomes as follows, 


$$
\begin{aligned}
X_{j t}= & \beta_{1 t}+\beta_{2 t} D_{j t}+R_{j t}\left(\mu_{1 t}+\mu_{2 t} M K V_{j t}+\mu_{3 t} M B_{j t}+\mu_{4 t} L E V_{j t}\right) \\
& +D_{j t} * R_{j t}\left(\lambda_{1 t}+\lambda_{2 t} M K V_{j t}+\lambda_{3 t} M B_{j t}+\lambda_{4 t} L E V_{j t}\right) \\
& +\left(\delta_{1 t} M K V+\delta_{2 t} M B+\delta_{3 t} L E V+\delta_{4 t} D_{j t} M K V+\delta_{5 t} D_{j t} M B+\delta_{6 t} D_{j t} L E V\right)+\varepsilon_{j t}
\end{aligned}
$$

As explained earlier, CRASH is the dependent variable, which measures stock price crash risk ratio and to measure this ratio we use a method proposed by Hutton et al. (2009). Table 1 demonstrates the summary of how to calculate all control variables,

\section{Table 1}

Description of calculation of control variables

\begin{tabular}{ll}
\hline Variable & Description \\
\hline DTURN & $\begin{array}{l}\text { This ratio is obtained through subtracting the mean monthly stock turnover of this year } \\
\text { from an average monthly turnover of stock years ago. }\end{array}$ \\
NCSKEW & $\begin{array}{l}\text { This ratio is obtained through dividing the third torque negative weekly return by the } \\
\text { standard deviation of weekly returns. }\end{array}$ \\
SIGMA & $\begin{array}{l}\text { Standard deviation of weekly return. } \\
\text { RET }\end{array}$ \\
This is the average weekly return. \\
MB & This is the natural logarithm of firms' sales. \\
LEV & This is calculated as a ratio of market value to book value. \\
ROA & The leverage is calculated as a ratio of long terms liabilities on total assets. \\
\hline
\end{tabular}

After gathering the necessary information, we need to first look at some basic information, which are summarized in Table 2 as follows,

\section{Table 2}

The summary of basic statistics on data

\begin{tabular}{lccccccc}
\hline Variable & Min & Max & First quartile & Third quartiles & Median & Mean & Standard deviation \\
\hline CRASH & 0 & 1 & 0 & 1 & 0 & 0.43 & 0 \\
CSCORE & -1.72 & 0.71 & 0.19 & 1.18 & 0.35 & 0.19 & 0.24 \\
DTURN & -0.5 & 0.5 & -0.0005 & 0.005 & -0.0002 & 0.0016 & 0.0545 \\
NCSKEW & 10.75 & 13.92 & 11.44 & 12.36 & 11.85 & 11.93 & 0.64 \\
SIGMA & -5.79 & 6.21 & -1.33 & 1.15 & -0.2346 & -0.06 & 2.09 \\
RET & -0.02 & 0 & -0.002 & -0.0006 & -0.001 & -0.0022 & 0.004 \\
SIZE & 0.12 & 0.22 & 0.035 & 0.06 & 0.047 & 0.056 & 0.03 \\
MB & 0.003 & 0.90 & 0.02 & 0.08 & 0.04 & 0.06 & 0.09 \\
LEV & -0.09 & 0.57 & 0.067 & 0.24 & 0.13 & 0.16 & 0.13 \\
ROA & 0.37 & 14.12 & 0.79 & 2.85 & 1.31 & 1.96 & 1.61 \\
\hline
\end{tabular}

Before, we perform regression analysis we need to make sure that all data are normally distributed and due to large number of observations, we believe the normality test holds for all the input data. We also need to make sure that there were no strong correlations among data and our investigation through Pearson correlation test confirmed this hypothesis. In our investigation, we performed logit regression analysis (Ai, Norton, 2003; Petersen, 2009) on the following model,

$\mathrm{CRASH}_{\mathrm{t}+1}=\alpha_{0}+\alpha_{1} \operatorname{CSCORE}_{\mathrm{t}}+\sum_{\mathrm{q}=2}^{\mathrm{m}} \alpha_{\mathrm{q}}\left(\mathrm{q}^{\text {th }}\right.$ ControlVariables $\left._{\mathrm{t}}\right)+\varepsilon_{\mathrm{t}}$

The proposed study uses the following for testing the hypothesis of the survey,

$$
\begin{cases}H_{0}: & \alpha_{1}>0 \\ H_{1}: & \alpha_{1}<0\end{cases}
$$


where the null hypothesis states that conservatism influences positively on stock price while the alternative hypothesis states that conservatism influences negatively on stock price. In this study, we use three models, the first mode considers five control variables of DETURN, NCSKEW, SIGMA, RET, and SIZE in the model and two variables of MBT and LEV are added to the second model in addition to the first five control variables. Finally, the last model considers ROA in addition to all previous seven variables. The coefficient of CSCORE is negative in all models. In our survey, all null hypotheses are accepted when the level of significance is five percent. The regression analysis uses panel data and the results of Durbin-Watson data were all within acceptable limit 1.5-2.5, which indicates there was no auto-correlation among residuals.

\section{Discussion and Conclusion}

In this paper, we have presented an empirical investigation using Logit regression analysis to find out whether conservatism behavior has any impact on stock market crash or not. The results of our survey have indicated that conservatism has negative impact on future stock market crash. The results of our survey are consistent with findings of Kim et al. (2011). In our survey, most control variables did not represent meaningful impact on stock crash and this is not consistent with the results of Chen et al. (2001) and Hutton et al. (2009).

\section{References}

Ahmed, A. S., \& Duellman, S. (2007). Accounting conservatism and board of director characteristics: An empirical analysis. Journal of Accounting and Economics, 43(2), 411-437.

Ai, C., \& Norton, E. C. (2003). Interaction terms in logit and probit models. Economics letters, 80(1), 123-129.

Ball, R., Robin, A., \& Sadka, G. (2008). Is financial reporting shaped by equity markets or by debt markets? An international study of timeliness and conservatism. Review of Accounting Studies, 13(2-3), 168-205.

Ball, R., Jayaraman, S., \& Shivakumar, L. (2009). The complementary roles of audited financial reporting and voluntary disclosure: A test of the confirmation hypothesis. Available at SSRN 1489975.

Ball, R., Kothari, S. P., \& Nikolaev, V. (2010). Econometrics of the Basu asymmetric timeliness coefficient and accounting conservatism. Chicago Booth Research Paper, (09-16).

Bates, D. S. (2000). Post-'87 crash fears in the S\&P 500 futures option market. Journal of Econometrics, 94(1-2), 181-238.

Beekes, W., Pope, P., \& Young, S. (2004). The link between earnings timeliness, earnings conservatism and board composition: evidence from the UK. Corporate Governance: An International Review, 12(1), 47-59.

Bekaert, G., \& Wu, G. (2000). Asymmetric volatility and risk in equity markets. Review of Financial Studies, 13(1), 1-42.

Boyer, B., Mitton, T., \& Vorkink, K. (2010). Expected idiosyncratic skewness. Review of Financial Studies, 23(1), 169-202.

Braun, P. A., Nelson, D. B., \& Sunier, A. M. (1995). Good news, bad news, volatility, and betas. The Journal of Finance, 50(5), 1575-1603.

Bushman, R. M., \& Piotroski, J. D. (2006). Financial reporting incentives for conservative accounting: The influence of legal and political institutions. Journal of Accounting and Economics, 42(1), 107-148.

Campbell, J. Y., \& Hentschel, L. (1992). No news is good news: An asymmetric model of changing volatility in stock returns. Journal of financial Economics, 31(3), 281-318.

Chen, J., Hong, H., \& Stein, J. C. (2001). Forecasting crashes: Trading volume, past returns, and conditional skewness in stock prices. Journal of Financial Economics, 61(3), 345-381. 
Chung, H. H., \& Wynn, J. P. (2008). Managerial legal liability coverage and earnings conservatism. Journal of Accounting and Economics, 46(1), 135-153.

Dhaliwal, D. S., Huang, S., Khurana, I., \& Pereira, R. (2008). Product market competition and accounting conservatism. Available at SSRN 1266754.

Dierker, M. (2006). Does conservatism help or hurt market efficiency?. Available at SSRN 895504.

Dimson, E. (1979). Risk measurement when shares are subject to infrequent trading. Journal of Financial Economics, 7(2), 197-226.

Duffee, G. R. (1995). Stock returns and volatility a firm-level analysis. Journal of Financial Economics, 37(3), 399-420.

Engle, R. F., \& Ng, V. K. (1993). Measuring and testing the impact of news on volatility. The Journal of Finance, 48(5), 1749-1778.

Frankel, R., \& Roychowdhury, S. (2007). Are all special items equally special? The predictive role of conservatism. The Predictive Role of Conservatism, Available at SSRN 1001434.

Kim, J. B., Li, Y., \& Zhang, L. (2011). Corporate tax avoidance and stock price crash risk: Firm-level analysis. Journal of Financial Economics, 100(3), 639-662.

Khan, M., \& Watts, R. L. (2009). Estimation and empirical properties of a firm-year measure of accounting conservatism. Journal of Accounting and Economics, 48(2), 132-150.

Lara, J. M. G., Osma, B. G., \& Penalva, F. (2009). Accounting conservatism and corporate governance. Review of Accounting Studies, 14(1), 161-201.

Glosten, L. R., Jagannathan, R., \& Runkle, D. E. (1993). On the relation between the expected value and the volatility of the nominal excess return on stocks. The Journal of Finance, 48(5), 17791801.

Harvey, C. R., \& Siddique, A. (2000). Conditional skewness in asset pricing tests. The Journal of Finance, 55(3), 1263-1295.

Hong, H., \& Stein, J. C. (2003). Differences of opinion, short-sales constraints, and market crashes. Review of financial studies, 16(2), 487-525.

Hutton, A. P., Marcus, A. J., \& Tehranian, H. (2009). Opaque financial reports, $\mathrm{R}^{2}$ and crash risk. Journal of Financial Economics, 94(1), 67-86.

Khan, M., \& Watts, R. L. (2009). Estimation and empirical properties of a firm-year measure of accounting conservatism. Journal of Accounting and Economics, 48(2), 132-150.

Kothari, S. P., Shu, S., \& Wysocki, P. D. (2009). Do managers withhold bad news?. Journal of Accounting Research, 47(1), 241-276.

LaFond, R., \& Watts, R. L. (2008). The information role of conservatism. The Accounting Review, 83(2), 447-478.

Marin, J. M., \& Olivier, J. P. (2008). The dog that did not bark: Insider trading and crashes. The Journal of Finance, 63(5), 2429-2476.

Norton, E. C., Wang, H., \& Ai, C. (2004). Computing interaction effects and standard errors in logit and probit models. Stata Journal, 4, 154-167.

Petersen, M. A. (2009). Estimating standard errors in finance panel data sets: Comparing approaches. Review of financial studies, 22(1), 435-480.

Pindyck, R.S. (1984). Risk, inflation, and the stock market. The American Economic Review, 74, 335351.

Qiang, X. (2007). The effects of contracting, litigation, regulation, and tax costs on conditional and unconditional conservatism: cross-sectional evidence at the firm level. The Accounting Review, 82(3), 759-796.

Roychowdhury, S., \& Watts, R. L. (2007). Asymmetric timeliness of earnings, market-to-book and conservatism in financial reporting. Journal of Accounting and Economics, 44(1), 2-31.

Van Buskirk, A. (2009). Implied volatility skew and firm-level tail risk. Unpublished paper, University of Chicago.

Zhang, J. (2008). The contracting benefits of accounting conservatism to lenders and borrowers. Journal of accounting and economics, 45(1), 27-54. 